\title{
Democracy and ecological governance - a balancing act
}

\section{Sustainability and democracy: a political dilemma}

Legitimising the balance between sustainability and autonomy; the need for democratic politics

As pointed out in Chapter 1, this book builds on the normative argument that ecologically rational governance must strive for sustainability within the limits set by democracy and individual autonomy. The relationship among these values is quite complex. On the one hand, effective and in the longer term successful ecological governance relies on quite radical changes in present values and behaviour in the direction of substantial restrictions on individual autonomy of choice. This could be used as an argument for constraints on democratic participation in order to prevent political conflicts and ease the introduction and implementation of radical measures (see Lafferty and Meadowcroft 1996:257). On the other hand, the very fact that progress towards sustainability presupposes far-reaching value changes implies that citizen participation would be a necessary prerequisite for successful ecological governance. Comprehensive value changes simply cannot achieve political legitimacy without widespread democratic participation in the process of change.

However careful the balance is struck between sustainability and autonomy in the practical implementation of ecological governance, there will be 'winners' and 'losers' in the conflicts over when, how, why and by whom resources should be used. The stronger the value of autonomy is pursued at present, the more individual actors today can utilise natural resources in ways 
not compatible with the need for long-term, sustainable resource management. Or to turn this argument around; the stronger the pursuit of long-term ecological sustainability, the more threatened may be the value of individual autonomy. While ecological governance for sustainability must profoundly affect all and everyone in order to be successful, it cannot achieve legitimacy without offering each and everyone a possibility to participate in the formation and implementation of such governance. Susan Baker has succinctly summarised this dilemma of ecological governance:

If new governance is to be increasingly relied upon as a way of governing the crisis of environmental governability, then new ways will have to be found to ensure greater societal participation in environmental policy-making while at the same time guarding against any erosion of the principles of democratic government. (Baker 2001:121)

Baker's last words are important; attempts to make ecological governance both effective and democratically legitimate are made in a context of traditional democratic processes. When a larger number of groups and interests are brought into such governance, 'special' interests are bound to appear. Such interests are often entrenched in policy communities or issue networks based on values contrary to sustainability, and might not necessarily take a favourable view of sustainable development. But locking out some groups from participation would mean a break with the values of democracy and individual autonomy. So, the efforts to bring about ecologically rational governance must ultimately observe the limits on their legitimacy drawn by the values of democracy and individual autonomy. Only when formulated and implemented in an open, participatory process of democratic decision-making could massive policy changes deeply affecting individual autonomy be considered legitimate and thus politically sustainable.

Participation and autonomy for whom: market actors or democratic citizens?

As the earlier chapters reveal, ecological governance for sustainability does have important spatial, temporal, cognitive, and integral implications for both the democratic process and its 
outcomes in terms of individual autonomy. Such governance creates new levels and new entities of governance, thus providing several new points of access for public participation in the policy process. It opens up new temporal dimensions, implying that the democratic process should take into consideration the interests of future generations not yet appearing on the political scene. By bringing in cultural traditions and local knowledge of man-nature relationships, widened participation challenges traditional methods of policy-making, where science and technology are used to determine 'objectively' the problems to be addressed. Perspectives of public participation and individual autonomy challenge the implementation of sustainability not just on whether or not integrative mechanisms effectively promote that value, but also on whether such mechanisms are consistent with individual freedom of choice and rights to self-determination.

How, then, could democratic participation be promoted and individual autonomy safeguarded in a system of governance geared towards ecological sustainability? In the latter half of the 1990s, it was increasingly argued that this question was wrongly put. Proponents of ecological modernisation held that promotion of green growth would do away with the presumed conflict between sustainability and individual freedom of choice. By promoting green growth, governments could provide a win-win solution in tune with the prevailing logic driving actors in the market (see Jansen, Osland and Hanf 1998:291 ff.). However, this view has been questioned on grounds of both sustainability and autonomy. As for sustainability, ecological modernisation 'follows, in essence, past patterns of economic development, particularly the equation of economic growth with human social progress' (Barry 1999:252 f.). A comparative study of West European environmental governance furthermore found evidence that "none of the most active promoters of ecological modernisation will achieve its goals in terms of the central categories and criteria of environmental policy' (Jansen, Osland and Hanf 1998:319).

In terms of democracy and individual autonomy, ecological modernisation is criticised because its strong emphasis on marketbased instruments addresses individuals and groups in society as producers and consumers rather than as 'democratic citizens under the law' (Barry 1999:227). It encourages people to think in 
terms of marginal behavioural change guided by the criterion of individual economic gain. This, argue the critics of ecological modernisation, is not compatible with the massive change in cultural values necessary to achieve ecologically sustainable development. Such changes must be based on free and informed deliberations on what the institutionalised societal values should really be about. This implies a concern with measures for participatory democracy where autonomous citizens are 'encouraged to consider the interests of all those potentially affected by the democratic process' (Barry 1999:228 f.).

When individuals are addressed as citizens, their sphere of autonomy is widened. They are empowered to participate in, and deliberate over which collectively binding decisions should be made with respect to resource use and management. Democratic governance, in which citizens also have a guaranteed sphere of influence over collective matters, is after all 'a process in which we all come to internalise the interests of each other and indeed of the larger world around us' (Goodin 1996:18). Goodin's words point out the dual nature of the sustainabilityautonomy relationship. A participatory democratic process offers the promise of respect for the integrity of the commons (citizens taking responsibility for the fate of the larger world surrounding them) as well as for the value of autonomy (citizens coming to respect the rights of other individuals). In conclusion, I agree with the argument that only through democratic participation can society create 'a shared public basis on which to ground the legitimacy of restrictions and corrections' that are considered necessary to achieve ecologically sustainable development (Achterberg 1993:91).

\section{Solving the dilemma: measures for participatory and legitimate} ecological governance

Much has been done to create such a basis since environmental policy became a policy field in its own right in the 1960s. The field has been marked by a distinctive drive for new means and channels of participation. Some argue that following the Rio Summit and the Agenda 21 process of the 1990s, 'citizen participation is seen as the defining characteristic of sustainable development' (Baker 2001:119). Compared to the 'traditional' policy-making process, many innovative measures have been 
introduced to bring different actors and the public together in free and open discourse to reach decisions through the strength of the better argument (Dryzek 1995:302).

Right-to-know legislation has been extended, and brought into use in processes of physical and infrastructural planning. The same is true for public hearings; it would nowadays seem almost unthinkable to launch large development projects without open hearings that involve affected interests. Environmental NGOs have enjoyed a firmer legal standing and widened possibilities of appeal. The concept and procedures of Environmental Impact Assessment, once introduced in the US National Environmental Policy Act, have found their way into a host of national legislations, thereby enlarging the public's possibilities of participation and influence. Environmental mediation and regulatory negotiation are examples of efforts to bring relevant actors and affected interests into the decision-making processes of ecological governance.

It should be noted that by being in essence a multi-level system of 'nested enterprises', ecological governance is dependent for its democratic legitimacy on each level having spheres of autonomy that allow for meaningful popular participation (Ostrom 1990: 89 f.). Decentralisation and delegation of authority and responsibility are called for in this respect, as are specific programmes directly addressing local and ecosystem-based entities of governance with recognised spheres of competence. The intergenerational perspective of ecological governance calls for mechanisms to enhance the interests of future generations. There are proposals to give rights to future generations in order to guarantee sustainability (see Wissenburg 1993). To pass the test of legitimacy, however, ecological governance must not only be 'just in time' but also 'just now', i.e., it must observe the rights and the autonomy of present generations. In line with the argument made on pages $148 \mathrm{ff}$. we could view several of the measures for increased participation as ways of safeguarding those values.

With respect to the democracy and autonomy aspects of ecological governance, the following criteria can be formulated:

- Governance is ecologically rational in terms of democracy to the extent that the management of environment and natural resources is subjected to political debate and decision-making 
in democratic processes open to meaningful public participation at all levels of governance.

- Governance is ecologically rational in terms of individual autonomy to the extent that the choices of policy measures used in such governance are made with a view to safeguarding individual rights both now and in the future.

In the following, I first of all analyse the formal regulations surrounding citizen access to public information in general, and on environment-related issues in particular, as well as the rules safeguarding individual rights and freedom of choice. Then I look into the points and channels of access and participation in the process of policy formation, followed by a study of participation in two processes of local ecological governance. The chapter then traces the official views of participation in future ecological governance, and ends with an analysis and judgement of how the discovered Swedish patterns correspond to the criteria just outlined.

Formal ecological governance in Sweden; access to the commons and enclosures for individuals

An open political process; common access to information

The Public Access to Information Principle has been a fundamental part of Swedish law since 1776. The present rules on public access to official documents are found in one of Sweden's constitutional laws - the Freedom of Press Act. They guarantee the right of Swedish citizens to obtain access and insight into administrative documents and activities. The principle furthermore means that the public and the mass media - newspapers, radio and television - have the right to obtain information about state and municipal activities (the following builds on Government Offices 2000). The principle is expressed in various aspects of access, freedom of expression and communication:

- Access to official documents;

- Freedom of expression for civil servants and others;

- Communication freedom for civil servants and others;

- Access to court hearings;

- Access to meetings of decision-making assemblies. 
The public access concerns official documents. A document is official if it is held by a public authority, or can be regarded as having been received or drawn up by a public authority. Drafts, written communications or other working material are not considered official if the draft is not used when the issue is finally decided upon, or if they have not been retained for filing. It is often easy to conclude that written paper documents are 'held' by a certain public authority. Electronically processed data, AV recordings, and the like are considered as held both by the public authority storing the recording, or having a computer terminal link-up, or having facilities to obtain printouts.

The character and topics of certain official documents qualify them as secret. This means that the public is not entitled to read the documents and the public authorities are forbidden to make them public. Official documents other than the following ones listed in the Freedom of Press Act may not be kept secret in order to protect interests:

- Sweden's national security and foreign relations;

- Sweden's central financial, monetary and foreign exchange policy;

- public authorities' inspection, control or other supervisory activities;

- prevention and prosecution of crime;

- Sweden's public economic interest;

- protection of individuals' personal integrity or economic conditions;

- preservation of animal or plant species.

Those wishing to obtain an official document (provided it is not judged to qualify as secret) have the right to read the document at the place where it is held. They are not required to describe the document precisely to obtain it. The authority must make available the necessary technical equipment for comprehending the document. Claimants are also entitled to obtain a transcript or a copy of the document for a fixed fee. As for computerised documents or data, authorities should provide printouts. Requests to obtain official documents must be dealt with speedily by the authority. Unnecessary delay is not permitted. Authorities cannot demand that persons who wish to obtain an official document identify themselves or state what the 
document will be used for. If a request relates to a document falling under some provision of the Secrecy Act, the authority has the right to ask the applicant about identity and purpose. If the applicant refuses, he or she relinquishes the possibility of obtaining it. If authorities reject the request for a document, or supply the official document subject to reservations, the applicant is entitled to appeal for a court review of that decision.

There should be no doubt that this constitutionally guaranteed openness is of utmost importance for the democratic character and the protection of individual autonomy in the processes of ecological governance. However, there have been concerns that the privatisation and contracting out of policy implementation as well as the Swedish membership in the European Union might shrink the citizens' possibilities to retrieve information for use in the democratic debate. In its January 2002 Democracy Bill, the Cabinet thus proposed that private firms contracted to carry out public duties, private schools with public financing, and the documents from preparatory bodies under the Municipal Council should fall under the principle of public access to documents. This may in fact be interpreted as a widening of public access from government to governance. Sweden furthermore succeeded in achieving its objective for the leadership term in Spring 2001 to widen public access to EU documents (see Cabinet Bill 2001/02:80, pp. 99 ff., 113).

Public access to the governance of the commons; the law of the land

To further illuminate the prospects for democracy and individual autonomy in ecological governance, let us now look more specifically into how access, participation and protection of individual rights are formally outlined in legislation pertinent to environmental and natural resource issues.

As mentioned above (see p. 126 f.) the 1998 Environmental Code is construed as an amalgamation of a large number of acts covering - in principle - every aspect of human activity that might have an impact on environmental quality and natural resources. Activities that are expected to have considerable such impacts must apply for permits, granted by the Cabinet, environmental courts, regional administrations, or local governments, depending on the scale of the activity and the scope of expected impacts. 
What is of particular interest here is how the Code regulates duties to provide information, as well as rights of participation in such processes. When laying out the law of the land in this respect, we will also be covering physical and infra-structural planning in general.

Descriptions and assessments of environmental impacts of everything from specific projects to general policies have been discussed and used in various ways ever since they were put on the books through the US 1969 National Environmental Policy Act. In ideal fashion, Environmental Impact Assessment (EIA) procedures involve not only descriptions of the proposed activity's potential environmental impacts, but also of such impacts from alternative ways of carrying out that activity. Furthermore, an ideal type EIA includes comparative evaluations and assessments of the environmental acceptability of these alternative courses of action. A basic idea behind the demands for EIAs is to provide possibilities for open debate on the proposed action, involving, e.g., those potentially affected by that action through access to public hearings, and rights of appearance and argument before the decision-making body.

A first, and rather limited version of the EIA procedure was introduced in Sweden in 1981, providing merely for description of potential impacts (EID) of projects needing permits under the Environmental Protection Act. This legislation at the same time made mandatory a procedure of early and active counsel between relevant authorities and affected interests before making decisions on projects potentially harmful to the environment. This thinner EID requirement was gradually made applicable to more and more issues and areas, particularly when several resource-related acts were put under the umbrella of the Natural Resources Act in the late 1980s. A National Audit Office review in the mid-1990s found several flaws in the EID procedures. The general public and environmental NGOs were often getting access too late in the process. EID reports often failed to describe the environmental impact of alternative ways of implementing large resource-related projects. EIDs of large water exploitation projects only described the impacts of profitable alternatives (National Audit Office 1996).

The 1998 Environmental Code contains specific regulation on the procedures and content of environmental impact assessments. 
All activities requiring a permit under the Code are subjected to the EIA requirement (Cabinet Bill 1997/98:145, pp. 278 ff.). Both the general public and particularly affected interests have the right to be informed of a pending permit application. They also have the right to comment on both the application and the related EIDs, the content of the latter being specified in the Code (Cabinet Bill 1997/98:145, p. 292). One could describe the new EIA as a two-step process. All actors in the process of applying for a permit must seek early counsel with relevant supervisory authorities, usually the Regional Administrations, and with potentially affected interests. At this stage, the applicant should provide at least a preliminary EID to allow for discussion of environmental impacts. Both affected interests and the general public have the right to present arguments at this stage (Cabinet Bill 1997/98:145, p. 282 f.).

In the second round, the general public and the affected interests have the right to retrieve information on both the application and the full EID, except for such details that can be labelled business secrets. The Code makes it mandatory for responsible authorities to announce publicly that the application is made and that an EID is available. This goes also for site inspections to allow for participation from the public and affected interests. The Code particularly regulates the procedures involving projects with 'considerable' potential effects on the environment. Should the supervisory authority find, after the first round, that this is the case, an enlarged EIA procedure is called for. An enlarged counsel is then mandatory, involving relevant national agencies, local governments, as well as environmental NGOs. Furthermore, all affected interests with a legal standing must be involved, i.e., those with property rights or with ongoing economic activities in the area where the applicant wants to locate the project. In terms of content, the EID must now cover all aspects of relevance, including alternative locations and - where possible - alternative technologies (Cabinet Bill 1997/98:145, pp. 286 ff.).

Seen in combination with the general rules of public access to governmental information, the EID/EIA requirements connected to the permit procedures laid out in the 1998 Environmental Code have increased the opportunities for citizens and potentially affected interests to retrieve information. The procedures guarantee public access to the proceedings of those authorities making 
decisions on permit applications, in most cases the Environmental Courts. While this could be seen as opportunities for the public to influence decisions in the direction of sustainable development, there is, as we have emphasised throughout this book, also another side to it, i.e., that of safeguarding autonomy. When there are such opportunities to protect and promote the value of sustainability, what happens to the protection of individual rights and the enhancement of individual autonomy in the sense of reasonable freedom of choice?

\section{Enclosures of the commons. Safeguarding individual rights and freedom of choice}

Much of the governance for sustainability is concerned with protecting and enhancing the viability and productivity of ecosystems. To this end, a common interest can be construed with regard to such values as biological diversity, water quality, etc. What occurs when a government or an authority decides to put certain claims and restriction on part of the territory (see above, p. 62 on the concept of 'national interest' in physical planning) is not just an 'enclosure' of the commons in the name of sustainability. It also constitutes an infringement on individual autonomy. Certain present or prospective economic and social uses of the land are put under restriction. Industrial and exploitative action is prohibited. Citizens used to enjoying the unique Swedish common law practice of Common Right to Access to all land not under cultivation find themselves fenced out or subjected to restrictions on their freedom of movement.

How does Swedish law strike the balance between preserving the integrity of the commons and valuing individual autonomy? Discussing this crucial issue in relation to the new Environmental Code, the Minister of Justice took as his starting point the Swedish constitution which states that to justify intrusions on private property and on individual rights, the common interest identified must be very 'important' or 'urgent'. The principle to be applied in relation to issues of ecological sustainability should, concluded the Minister, be that they are often of such importance or urgency as to motivate intrusions on individual rights. While such intrusions always presuppose a reasonable proportionality between common gain and private loss, the wording of the Code Bill implies that the future balance might be shifted towards a 
broader interpretation of common gain (Cabinet Bill 1997/ 98:145, pp. 320 ff.).

Thus, the scope or magnitude of intrusions on behalf of sustainability might increase over time. If intrusions on private property and individual freedom become broader and more frequent, the issue of compensation becomes even more crucial than before. The Environmental Code deals with compensation in the traditional Swedish way. Compensation is afforded when decisions to establish areas of nature conservation, biodiversity and water protection or cultural reserves involve appropriation of land or make on-going land-use 'essentially more difficult' in the 'affected part of the property' (Cabinet Bill 1997/98:145, pp. 546 ff.).

Why this particular delineation of the circle of actors entitled to compensation? What about the general public suddenly closed out from areas of common access as a result of new economic activities permitted under the Environmental Code? To answer this question, one is forced to analyse the concept of 'legal standing' and its implications for individual autonomy. As we saw earlier, both the general public and the property owners in an area affected by a proposed economic activity with potentially harmful environmental consequences have the right to state their case in a permit proceeding. But in traditional Swedish legislation related to natural resources, legal standing in the sense of right to appear and right of appeal was offered only to those owning adjacent property. As for the Environmental Protection Act, legal standing in this sense was linked to those caused to suffer definable damage or some other inconvenience from environmentally harmful activities, not necessarily owning property. The Environmental Code establishes a more uniform concept of legal standing, based on this latter interpretation. However, those made to suffer because there are infringements on the Rights of Common Access are not afforded legal standing (Cabinet Bill 1997/98:145, p. 485 f.). It goes without saying that this excludes a large potential circle of actors from legal rights of appearance.

However, the Environmental Code also contains some new statutes enlarging the possibilities for environmental group action. This comes in the form of a right to legal standing for environmental NGOs. Such organisations can, as we saw earlier, participate in the decision-making processes on permits under the 
Code. What is really new is that such NGOs now also have the right to appeal against decisions by permit-granting bodies. Provided such organisations are open to all, have been active for more than three years, and provided further that they have a membership of more than 2,000 persons, they can appeal against permit decisions, and environmental court rulings, as well as decisions to exempt some activity from Environmental Code procedures. They can act on behalf of common environmental interests, or on behalf of some particularly affected interests (Cabinet Bill 1997/98:145, pp. 487 ff.).

To summarise, the law of the land provides citizens and affected interests with several formally guaranteed opportunities for becoming informed and participating in the policy process. There may of course be some unequal distribution of capabilities among different categories of actors and interests to fully utilise these opportunities. What becomes crucial is the extent to which governments at different levels actually live up to the provisions for public participation and the right of individuals to be informed on issues that may affect their rights and future freedom of choice.

Participation in Sweden's ecological governance: who is, and who should be sharing the commons of policy-making?

\section{Commissioned to participate: organised interests and environmental policy-making}

Governmental commissions are very important vehicles for policy formation in Sweden. Working on terms set up by a Ministry, a commission investigates a policy problem and reports back to the Ministry. The composition of commissions may vary depending on the perceived political centrality of the problem. The more crucial the topic in the eyes of the government, the more carefully balanced is the representation. Commissions may be parliamentary, meaning that the political parties are represented, or representative of the interests perceived to become affected by the reform proposals of the commission, or they may be expert commissions to deal with a more technical problem. It is quite usual for commissions to establish close contact with public agencies, industrial branch organisations, NGOs, and individual experts during their period of investigation. They may also arrange hearings on particular topics related to their terms of 
reference, or use such hearings for testing out some of the proposals contemplated. Commissions are thus very important as a means of bringing in and accommodating the views of different political, economic and social interests in Swedish society. They have been described as vehicles for producing relevant knowledge on social problems, as an arena for crafting compromises and creating consensus, and as a Cabinet instrument for strategic political planning (Johansson 1992:17).

What happens after the Commissions present their reports is equally important for the possibilities of participation in policymaking. The reports are usually sent out to all relevant authorities with a 'request' to comment. 'Invitations' to comment are also sent to branch organisations and NGOs related to the report's topic. In principle, the opportunity to provide written comments is accessible to everyone interested in the topic. Together with the original commission report, these 'remittals', i.e., written comments, are then used as the basis for the Cabinet Bills sent to Parliament (Uhrwing 2001:71 ff.).

Commission reports on issues related to sustainable development are thus of utmost importance for the democratic aspects of ecological governance. The proposals in these reports set the agenda for the further stages of the policy process. In so far as the suggestions of these reports are not vehemently challenged in the remittal process, they usually find their way into a Cabinet Bill. When the Cabinet enjoys a majority in Parliament, the sometimes only slightly modified Commission proposals become the law of the land. In this and the following part, we will look into (a) the scope and reach of participation in commissions related to ecological governance, and (b) the content of recommendations for public participation proposed by the two commissions on NEOs and climate reporting in 2000 .

A recent study of three environmental policy-making processes analysed the scope and reach of interest participation, from commissions all the way through to the submission of written comments and appearances before ministers and department officers. Interests are not only represented as members on the commissions. They are also participating through experts working for the commissions. Furthermore, they are invited for counsel and to hearings during the early stages of the commissions' work. But there is also a reverse process. Interest 
organisations initiate contacts with the commissions both formally and in more informal ways. After the commission report, vast numbers of interest organisations take part in the 'remiss' procedures. This participation comprises not only those organisations invited to give comments, but also those sending in comments on their own initiative. In fact, in two of the three policy-making processes under scrutiny, the number of voluntarily provided comments turned out to be larger than that of those invited. In the case of the commissions reporting on Sustainable Development in Sweden's Mountainous Regions, the number of voluntarily provided written comments was quite large. This was in no small amount the effect of the nation-wide association of snow-scooter owners' campaign to have small local scooterowner clubs sending in comments to protect their interests of free movement in the mountains (Uhrwing 2001, passim).

Two major commission reports related to sustainable development were presented to the national government in the year 2000. Both the Commission on National Environmental Objectives (NEOs, see above, p. 65 f.) and the Climate Commission were parliamentary. Representatives of the political parties investigated future policy alternatives for sustainable development assisted by experts and representatives of affected interests. Both provide typical examples of how commissions are used for gathering knowledge, creating consensus and help the Cabinet set the political agenda.

The NEO Commission was parliamentary; all parties in the Riksdag were represented. The membership further comprised several central agency officers. Of the 19 experts working in the commission, four came from interest groups, while the other 15 represented Cabinet ministries. The Commission took in a large amount of material from a total of 44 governmental agencies and regional administrations. Part of that material was based on a process of counselling between agencies and organised interests. Furthermore, the Commission instituted five thematic Working Groups. These groups arranged seminars involving both experts and organised interests. The Commission furthermore coordinated its work through counselling with no less than 14 other Commissions. Five hearings were held with business organisations and NGOs to provide for consensus and 'anchoring' of the proposals (SOU 2000:52, pp. 93 ff., Apps. III, IV, and VIII). 
Table 6.1 Categories of suppliers of written comments (Remiss) on the NEO and Climate Commission Reports

\begin{tabular}{|c|c|c|c|c|c|c|c|c|c|c|c|}
\hline \multirow[t]{3}{*}{ Report } & \multicolumn{11}{|c|}{ Suppliers of written comments } \\
\hline & \multirow{2}{*}{$\begin{array}{l}\text { Central } \\
\text { Agencies }\end{array}$} & \multicolumn{2}{|c|}{ Regional level* } & \multirow{2}{*}{$\begin{array}{l}\text { Local } \\
\text { govt's }\end{array}$} & \multirow{2}{*}{$\begin{array}{l}\text { Labour } \\
\text { market } \\
\text { org's }\end{array}$} & \multirow{2}{*}{$\begin{array}{l}\text { Business } \\
\text { org's }\end{array}$} & \multicolumn{2}{|c|}{ NGO's } & \multirow[t]{2}{*}{ Courts } & \multirow{2}{*}{$\begin{array}{l}\text { Research } \\
\text { inst's }\end{array}$} & \multirow[t]{2}{*}{ Total } \\
\hline & & $\begin{array}{l}\text { Reg } \\
\text { Adm's }\end{array}$ & $\begin{array}{l}\text { County } \\
\text { Councils }\end{array}$ & & & & Env. & other & & & \\
\hline $\begin{array}{l}\text { NEO } \\
\text { Commission } \\
\text { SOU 2000:52 }\end{array}$ & 43 & 21 & 5 & 14 & 3 & 44 & 6 & 23 & 2 & 19 & 180 \\
\hline $\begin{array}{l}\text { Climate } \\
\text { Commission } \\
\text { SOU 2000:23 }\end{array}$ & 28 & 5 & 1 & 8 & 6 & 52 & 8 & 9 & 4 & 23 & 144 \\
\hline
\end{tabular}


The Climate Commission was also parliamentary with all Riksdag parties represented. The membership further comprised several central agency officers. Expertise was linked to the Commission in the form of an economist advisory group, and there was close co-operation with relevant central agencies. Two hearings were held with representatives of business organisations and NGOs (SOU 2000:23, p. 1 f.).

The following stage of providing for written comments from central agencies, affected interests, and others affected by and/or interested in the topic, included a very wide spectrum of the Swedish society. The large number of central agencies involved is a reflection of the fact that they are most often requested and not just invited to supply comments, as are all or a specified number of regional administrations. Research institutions are frequent remiss providers. Perhaps the most remarkable pattern from these two reports is the heavy representation of business organisations, while voluntary NGOs, particularly those with an environmental agenda, are less prominent. This is of course very much due to the small number of nation-wide environmental NGOs in comparison to business.

As revealed by Uhrwing's recent study (2001) of interest organisations' access to the corridors of power, however, there are also other, and for the prospects of democratic ecological governance somewhat disturbing factors at work here. Uhrwing seeks to find out for whom participation in these forms and stages of policy formation for ecologically sustainable development really provides means for influence. She concludes that while the remittal of written comments is open to all, it is by and large mostly a symbolic form of participation. What really counts is to be a member of, or provide experts to, a Commission. However, she also finds that to get access to such positions in the process, organised interests seem to have to possess certain characteristics. They must be large enough to afford full-time secretariats and to have their own, in-house expertise. It furthermore helps if a business/labour organisation or a voluntary NGO is dominant within an area under investigation by a governmental commission.

By far, however, the most important conditions for access to the innermost rooms of power relate to the nature of expertise that organised interests and others can provide. What Uhrwing calls the technocratic norm prevails. This norm builds on the assump- 
tion of an 'immense need for information and technical expertise. Therefore, this kind of information and expertise was demanded from interest organisations if they wanted to gain access to the most meaningful forms of participation in the processes' (Uhrwing 2001:301). Not surprisingly, business organisations much more often have the resources necessary to participate on these conditions, and are thus able to get greater access into the corridors of power than NGOs presenting their argument in what would be interpreted as much more value-laden terms.

\section{Participation in ecological governance: active citizens or incentive-reacting consumers?}

Given Uhrwing's conclusions about the importance of specific organisational resources for effective participation and influence, it is of interest to compare the contents of recommendations for participation in three commission reports issued in the year 2000, all with a bearing on the future of Sustainable Sweden. The very first commission to report in the new millennium was that of the parliamentary Democracy Commission. Entitled Sustainable Democracy!, its 300-page report discusses the prospects for a widened democratic citizenship. The Commission leaned heavily on the discourse on deliberative democracy, and contended that representative democracy is not enough. Citizens should be allowed to commonly deliberate on different political solutions and their consequences throughout the policy-making process so that they are provided with real possibilities of influence (SOU 2000:1, Ch. 1).

The Democracy Commission thus saw active citizenship as a condition for sustainable democracy. When citizens discern a clear relationship between participation and the content of public decisions, there are good prospects for a sustainable democracy with trusted political institutions and highly legitimate policy decisions. Given the allusion to sustainability in the title of the Commission's report, one is led to assume that this would particularly hold for the democratic challenges posed by the quest for sustainable development. These challenges are after all prime examples of problems closely related to citizen participation and political legitimacy.

Thus it is of crucial interest to find out how democratic participation is treated in the two major commission reports 
related to sustainable development and issued in the year 2000. As already pointed out, both the Commission on National Environmental Objectives and the Climate Commission were parliamentary. Representatives of the political parties investigated future policy alternatives for sustainable development assisted by experts and representatives of affected interests. Indeed, the title of the 400-page NEO Commission report - The Future Environment - Our Common Responsibility - would seem to indicate a participatory perspective to legitimise political action with a cross-generational time horizon. On the other hand, the Climate Commission's 500-page report - Proposals for a Swedish Climate Strategy - leads one to think of an imminent battle rather than common democratic deliberations. As it turns out, both commissions seem to play on themes not totally in harmony with the ideas of democratic citizen participation. Contrary to the perspectives of the Democracy Commission, we are here confronted with a top-down perspective, where actions are to be taken not in dialogue with participating citizens, but for the most part in the form of signals to consumers and customers to change their market behaviour.

A content analysis of the three commission reports confirms this conclusion. As shown in Table 6.2, the Democracy Commission refers to individuals as 'citizens' 250 times, i.e., a rate of nearly once every page. Of the 174 times individuals are referred to in some other capacity the market-related epithet 'customer' appears only seven times. In the two reports on ecologically sustainable development, however, the perspective is opposite. The NEO Commission and the Climate Commission refer to 'citizens' only sixteen times in their total 1,900+ pages.

Indeed, the dominant view of two reports on sustainable development and future ecological governance puts that of the Democracy Commission on its head. Whereas that commission refers to citizens in a positive and active context 119 times, it refers to civic 'duties' only five times. The Climate and NEO Commissions view individuals mainly as customers and consumers, passive in the political sphere and predominantly acting on signals in the market. The NEO Commission refers to active consumers, while the Climate Commission tends to treat individuals as passively reacting to market incentives rather than actively participating in the collective decision-making process. 
Table 6.2 Group references, and initiation and direction of activities, in three future-related Swedish Commission reports issued in the year 2000

\begin{tabular}{|c|c|c|c|c|c|c|c|}
\hline \multirow[b]{2}{*}{$\begin{array}{l}\text { Commission } \\
\text { report }\end{array}$} & \multicolumn{2}{|c|}{ Group reference } & \multicolumn{5}{|c|}{ Initiation and direction of activity } \\
\hline & Citizen & $\begin{array}{l}\text { Customer/ } \\
\text { consumer/ } \\
\text { individual }\end{array}$ & Dialogue & $\begin{array}{l}\text { From } \\
\text { citizen }\end{array}$ & $\begin{array}{c}\text { Towards } \\
\text { citizen }\end{array}$ & $\begin{array}{l}\text { From } \\
\text { customer/ } \\
\text { consumer/ } \\
\text { individual }\end{array}$ & $\begin{array}{c}\text { Towards } \\
\text { customer/ } \\
\text { consumer/ } \\
\text { individual }\end{array}$ \\
\hline $\begin{array}{l}\text { Democracy } \\
\text { Commission } \\
\text { SOU 2000:1 }\end{array}$ & 250 & 174 & 4 & 115 & & - & - \\
\hline $\begin{array}{l}\text { NEO } \\
\text { Commission }\end{array}$ & & & & & & & \\
\hline SOU 2000:52 & 10 & 358 & 5 & - & - & 48 & 18 \\
\hline $\begin{array}{l}\text { Climate } \\
\text { Commission } \\
\text { SOU 2000:23 }\end{array}$ & 6 & 109 & - & 4 & 5 & 10 & 22 \\
\hline
\end{tabular}

Sources: SOU 2000:1, 2000:23, and 2000:52 
Thus, the commissions on sustainable development seem to act as if the normative issues of ecological governance are already settled. To a large extent, the role of the individual is reduced to one of 'changing behaviour' in response to future policy. This policy is often the result of negotiations over very specific issues of policy implementation among authorities, branch organisations, and individual enterprises. Now, one could of course argue that issues of ecological governance concern problems that are so complex both technically and politically as to render it well nigh impossible to accommodate broad public participation. There is need for expert judgement, and there is need for a distribution of roles between state and market. But as argued above, neither technological expertise, nor business calculi can claim legitimacy when it comes to which values should be guiding the future ecological governance and the society-environment relationship to be achieved by such governance. The question, then, is whether the general pattern found through our content analysis holds up when we analyse how citizens actually participate in the implementation of policies related to ecological governance. Two cases are of special interest here; the Swedish Local Agenda 21 process, and the implementation of the government's support to LIPs for sustainable development (see above, pp. 32 ff., 76 ff.).

\section{With or without the people: democratic ecological governance in practice}

\section{Ecological governance with the people? Sweden and Local} Agenda 21

Swedish local governments enjoy a constitutionally guaranteed autonomy on matters related to the welfare of its inhabitants and the development of the municipality. Local governments have a monopoly on physical and infrastructural planning within their boundaries, although such planning is subject to restrictions placed by environmental law and regulations safe-guarding individual rights to welfare, security and property. Local governments also have the right to tax the income of their inhabitants, and to enter into agreements with other municipalities to provide different welfare services (see Lundqvist 1998).

The Swedish Local Agenda 21 process began within a year after the 1992 Rio Conference, and covered most municipalities 
in Sweden (Cabinet Bill 1993/94:111 p. 64; see Eckerberg et al. 1997; see above p. 33). An internationally unique activity was launched to engage grassroots citizens and interest organisations in outlining visions and developing programmes for local sustainable development. Very early on, in 1994, central government formulated a national plan for Agenda 21, and the Environment Ministry presented a guide for Local Agenda 21 in the same year (Cabinet Bill 1993/94:111; SOU 1994:128). The purpose of the National Committee for Agenda 21 set up in 1995 was to stimulate local work on Agenda 21 as well as to take in data from local experiences. To this end, the National Committee arranged several meetings at the regional level as well as with different sectors of society. The Swedish Association of Local Authorities (SALA) continued to stress the bottom-up approach by collecting information and spreading data in order to support LA 21 activities among its members, i.e., the local governments (Eckerberg 1999:19 f.).

Already in 1996, about half of Sweden's 289 municipalities had employed special LA 21 officers. Two years later, 70 per cent of the local governments had employed a full-time or part-time Agenda 21 co-ordinator. It should be noted that this increase was supported by central government, which used money from the labour market funds to finance local hiring of such co-ordinators. By the end of 1998, 56 per cent of Sweden's 289 municipalities had local Agenda 21 plans. As for the political status of these plans, it is notable that most of them had been formally adopted through decisions by the Municipal Councils. Furthermore, most local governments located responsibility for co-ordination of LA 21 directly with the Municipal Board, i.e., the leading popularly elected Council politicians, whereas only about one tenth located it with the Environment and Health Board (Eckerberg et al. 1997:56 ff.; Eckerberg 1999:16 f.).

This political treatment of the issue and the allocation of coordinating responsibilities can be seen as an indication that Agenda 21 was perceived as extending beyond traditional environmental policy to involve all aspects of sustainable development. One close observer of the Swedish LA 21 process argues that there is tendency to emphasise the ecological over other aspects, both at the local level and in national programmes. Agenda 21 is largely perceived as a renewal and expansion of 
environmental policy, not involving economic and social aspects. Indeed, most LA 21 co-ordinators have been drawn from the community of environmental professionals (Eckerberg 2001:17).

Municipal action on LA 21 did not stop at planning. Four out of five municipalities have allocated special funding towards LA 21 activities. The level of funding increased somewhat since 1995. This said, one should note that while some local governments keep up the funding, others have cut down their LA 21 budgets. However, there is a tendency towards a growing gap between 'pioneering' municipalities and those who have cut down on staff and resources for LA 21. About 30 per cent have reduced their inputs in terms of both funding and staff (Eckerberg 2001:17).

A survey carried out in late 1998 found 97 per cent of the municipalities reporting quite conscious steps to engage citizens and interest groups in the LA 21 process. Two thirds of the municipalities arranged special courses and seminars or held open hearings and discussion meetings. Over 70 per cent of the municipalities provided LA 21 information brochures or leaflets to local households, or arranged exhibition and market events. Voluntary study organisations and environmental movements were engaged in over half of the municipalities. Every second local government made conscious efforts to involve village and community based voluntary organisations. About two thirds of the municipalities reported that they had established some permanent forum for exchange of ideas around LA 21 (Brundin and Eckerberg 1999). Studies of 'pioneer' municipalities further reveal this participatory thrust. One municipality engaged LA 21 workers in home visits to most of the municipality's households. Leading politicians within some local governments have taken part in initiating bottom-up projects (Eckerberg et al. 1997: 69 f.).

What, then, has actually been achieved in terms of public knowledge and involvement? A national survey in 1996 revealed that about 40 per cent of the population had knowledge of the Local Agenda 21 concept. About 20 per cent recognised at least one on-going LA 21 project, while only three per cent were actually involved in such a project (Eckerberg 1999:21). This may seem like a disappointing figure, given the massive information activities. A closer study of local governments that have formed consultation groups for LA 21 indicates the difficulties of citizen 
involvement in decision-making. The experience is that it is easy to create interest in 'neighbourhood' issues, but more difficult when broader issues are on the agenda. This holds even if the message of sustainable development is made as operational and simple as possible. The study concludes that 'even where great efforts were made to create conditions for participatory democracy, the results are often discouraging in terms of maintaining this interest' (Eckerberg 2001:33).

All in all, however, the major impression of the Swedish LA 21 process is one of strong emphasis on participation and information to the public, and of a conscious interplay between national initiatives and local action. This is not the least revealed in the titles of contributions from Swedish researchers to comparative studies on LA 21 implementation. Sweden has been seen as 'setting the pace', as combining municipal and national efforts for 'quick progress', and as being 'at the leading edge' in the LA 21 process. In a 1999 comparison, Sweden scored highest among the studied countries in terms of timing and broad-based implementation (Eckerberg, Coenen and Lafferty 1999:242 ff.). The crucial question, however, is how strong this local participatory process really is. What happens to citizen participation when Swedish local governments are targeted for central government funding to promote local investment programmes for sustainable development?

\section{Ecological governance without the people? Local management of the LIP process}

When the Social-Democratic Cabinet launched its programme to fund Local Investments Programs (LIPs) for Sustainable Development in 1997 (see above, pp. 78 ff.), municipal governments were, as we have seen, amidst the LA 21 process. Almost three out of five Swedish municipalities had adopted Agenda 21 action plans for sustainable development by 1998, and most of these plans were adopted during 1997, i.e., just about the same time as the central government launched the LIP process. The central government's view of the relationship between the LIPs and the LA 21 process was summarised by the 1997 National Agenda 21 Commission's report. LIP 'is directly linked to the Local Agenda 21 process. In this way, a linkage has also been established between the local level and the central decision- 
making functions of the Cabinet and the Parliament' on issues of sustainable development (SOU 1997:105, p. 11). In its budget bill for 1998, the Cabinet stated that local support is required in order for the ecological dimension within societal development to succeed' and that 'local Agenda 21 work should be brought into the investment programme' (Government Bill 1997/98:1, Spending Area 18, p. 43).

One would thus expect a rather close relationship in content between municipal LA 21 plans - many of them worked out in dialogue with local citizens, NGOs and other associations - and the LIP applications sent in to the Environment Ministry. One could also interpret the Cabinet's wordings as an expectation of an LIP process on the local level as participatory as that of LA 21. However, nation-wide surveys of the LA 21 co-ordinators do not seem to corroborate these assumptions. These key actors seem doubtful about the connections between the two programmes. This holds both for municipalities receiving grants as well for those not succesful in getting grants. Only five per cent of the LA 21 co-ordinators considered the two programmes closely connected, while close to half said they were partly connected. Ten per cent reported no connection whatsoever, and two out of five co-ordinators did not know of any such connection. Having focused on 'soft' sectors and broad citizen participation in the LA 21 process, local governments now looked to 'hard' sectors and to local business elites in the LIP programme (Brundin and Eckerberg 1999). Whereas the LIP programme focused on ecological efficiency through ecological modernisation, LA 21 was concerned with a much broader range of activities (see Eckerberg 2001).

The two programmes also seem to differ substantially in terms of local participation, particularly when it comes to what groups or circles of actors were involved. Only one third of the local branches of the Swedish Nature Conservancy Organisation - the leading Swedish environmental interest group - were invited by local governments to comment on LIPs in the first round of applications (Kågesson and Lidmark 1998). When preparing for the second, 1999 round of LIP applications, one fourth of the local governments engaged their citizens in the process through the creation of networks and other methods. However, contacts with local business were much more lively. As many as three out of 
four municipal LA 21 co-ordinators reported that local industry and business had been involved in the process of applying for a LIP grant. This is quite different from the LA 21 process, where just over one third of the municipalities reported a high degree of business involvement. The grassroots perspective so evident in the LA 21 process was thus much less prominent in the LIP process (Brundin and Eckerberg 1999).

In fairness, however, one should point out that there are variations to this pattern. The National Audit Office found both municipalities with broad involvement from the population, and others where the links to the local scene were quite weak (National Audit Office 1999b:53 ff.). One reason given by local governments was that the short time for LIP applications made it difficult to 'establish a broad citizen participation' in the process (Auditors of Parliament 1998/99:52). Given this, there would seem to have been all the more reason for the municipalities to build upon the already available LA 21 plans that enjoyed broad popular recognition and support from local networks. Evidently, however, many local governments actually preferred to put forward other projects - often involving infrastructural developments based on energy efficiency and increased employment - in co-operation with local economic interests. In a quite considerable number of cases, the LA 21 achievements thus seem to have been neglected. The LIP process thus came close to 'governance without the people', and - in effect - also local 'implementation from above' (see Lundqvist 2001a).

We thus encounter two local processes and two patterns of participation. One is geared towards citizen involvement all the way from ideas and visions to practical measures. The other seems more linked to socio-economic interests with resources of importance to the success of the local investment programmes. A most crucial question thus arises: Given these patterns, and given further the inclination towards market-based action to achieve sustainable development found in our content analysis of recent commission reports, what is the official view of participation and involvement in Sweden's future ecological governance? 
Sustainability and democratic participation: does Sweden solve the political dilemma?

Towards sustainable public participation? National government and the 'new ecological governance'

Already the title of the NEO Commission's report - The Future Environment - Our Common Responsibility - makes allusions to participation for all and everyone. And the opening phrases of the report's chapter on 'The New Environmental Work' (a literal translation; my remark) seem to corroborate this impression:

The objective of solving the large environmental problems of today within one generation demands widespread participation. It cannot be unilaterally realised by legal and administrative action. It is necessary for all to take on this responsibility. (SOU 2000:52, p. 115)

This is reiterated in the Cabinet's NEO bill accepted by Parliament. Legal and administrative action may provide a basis for action, but that action must involve all and everyone. At the same time, there is an undercurrent indicating that the objectives of widespread responsibility may not solely be to guarantee individuals some influence as subjects in the structures and processes of ecological governance. The diffusion of responsibility is part of a conscious effort to establish consensus and co-operation around specific views and strategies for sustainable development:

The new NEO structure provides for comprehensive and effective environmental management with participation from all strata in society. A common framework of objectives gives the direction for how to achieve an ecologically sustainable society through management by objectives and results. (Cabinet Bill 2000/01:130, p. 18; italics mine)

When we turn to how and in what capacities these 'strata in society' are to participate and take responsibility, a very special pattern emerges. The Cabinet actually begins its outline of the new environmental governance by discussing environmental behaviour from the viewpoint of the individual as a market actor responding to economic signals. Thus, economic and communicative policy instruments are seen as major ways of distributing responsibilities in accordance with the environmental load caused by the individual. Furthermore, the Cabinet sees pressures from 
customers and market demands as equally important driving forces for business as regulatory and administrative measures (Cabinet Bill 2000/01:130, p. 18 f.).

Indeed, firms and enterprises stand out as very important actors. By responding to customer pressures and market demands through measures such as EMAS, environmental certification, and eco-labelling of products, and by assuming the producer liability throughout the product's lifecycle, these economic actors are at the centre of 'new environmental governance'. The concept of 'sectoral responsibility' is central to the achievement of the NEOs. Public authorities and business share 'sectoral responsibility' for NEO achievement in the respective sectors. And while the Environmental Code and ensuing legislation and administrative guidelines provide the basis for environmental governance, regulatory power should be used sparingly, and complemented by other strategies. Indeed, the NEO bill foresees a specific mode of governance that both echoes Sweden's historic adherence to welfare state corporatism and resembles modes of environmental governance found in, e.g., the Netherlands. A core element in 'new environmental governance' will consist of voluntary agreements between government and business, where 'affected firms and sectors take a large responsibility for active environmental management' (Cabinet Bill 2000/01:130, pp. 19 ff.).

What then, about voluntary organisations and NGOs as representatives of individuals and groups interested in or affected by the ecological governance just outlined? The Cabinet Bill accepted by Parliament deals explicitly with such organisations and their role in a mere 12 lines out of a total of 10 pages discussing 'new environmental governance'. The Bill acknowledges that voluntary NGOs have for decades carried out activities of great value for the environment. On such issues as nature conservancy and ecolabelling, they have even spearheaded policy development. Continues the Bill:

It is the Cabinet's view that free, active and radical environmental NGOs, networks and other organisations acting on the basis of voluntary engagement will play important roles also in future environmental governance. Thus, environmental NGOs should also in the future act autonomously and independently of government, at the same time as they enjoy recognition and support from the authorities. (Cabinet Bill 2000/01:130, p. 19) 
When going more deeply into the Government's argument on who should be at the centre of future ecological governance, we thus find corroborated the pattern revealed by the content analysis of key Commission Reports. Individuals are primarily viewed as market actors responding to market signals. These signals will increasingly be formed in accordance with agreements among the actors really occupying centre stage in Sweden's 'new ecological governance', i.e., public authorities and business organisations sharing and acting out their 'sectoral responsibility' for NEO achievement.

Democracy and autonomy in Sweden's ecological governance; what will elites and citizens share in common? What, then are the prospects for democracy and individual autonomy in ecological governance? To say the least, we have discovered a mixed pattern. On the one hand, we have found that the law of the land is quite generous. The public's right to get access to official documents related to broad policy-making or to particular decisions affecting individuals, groups, or their environment is wider and more far-reaching than in most other countries. Affected interests enjoy the right to early counsel on resource- or environment-related issues requiring permits under the Environmental Code, as well as to take part in public hearings and site inspections. The concept of legal standing in such processes now also includes those affected interests not owning adjacent property, thus enlarging the enclosure around individual rights and individual autonomy. And - most notable in the Swedish context - environmental NGOs have been afforded legal standing as plaintiffs; they can appeal against decisions on behalf of the common interest. Furthermore, we have found that the policy process is quite open. Organised interests regularly participate as members. All such interests, as well as any individual interested in a policy proposal formulated through a governmental commission, are free to provide written comments to the government.

On the other hand, we have found that in reality, these formal possibilities are not used in full, or envisaged to be used in full, to create deliberative democratic ecological governance characterised by widespread participation. Started with much fanfare and backing from central and local government, and seeing more grass- 
roots activity than in most other countries, the Swedish Local Agenda 21 process has lost some of its momentum to become - at best - a routine activity entrenched in municipal bureaucracy. When central government began waving wads of money before local governments to engage them in the LIP process, many municipalities seemed to skip the participatory LA 21 process for that of BAU - Business As Usual. This meant working out local LIPs emphasising jobs and infrastructure development in co-operation with local elites. And - most notable - the future 'new environmental governance' envisaged by major Commissions and acknowledged by Parliament seems to build on a triumvirate. Carrying out their joint 'sectoral responsibilities', governmental agencies and organised business interests are expected to interact to provide customers with economic incentives and communicative signals to change towards more sustainable behaviour. The Swedish wordings on the future role of environmental NGOs could in fact be interpreted as 'an invitation with the elbow'. They are 'allowed' to continue their activities as voluntary organisations within ecological governance.

This mixed pattern lends itself to different interpretations. If we adopt an 'elite-centred' view of participation, Sweden's 'new environmental governance' might look like co-operative management regimes. Such regimes involve 'a number of social partners in a collaborative attempt to resolve specific environmental difficulties'. The use of Commissions, the remiss procedure, and the public access to official documents could be taken as corresponding to one characteristic of a regime that rests on processes of open, discursive consensus formation. Furthermore, the sectoral responsibility shared among governmental agencies and organised sectoral interests - officially viewed as a core element in the 'new environmental governance' - implies that once the parties have come to some agreement, they assume some joint responsibility for implementing that agreed-upon strategy. It may even be argued that by incorporating the 'mobilisation, complianceenhancing and legitimating potentials' of crucial socio-economic organised interests, central government tries to ensure that $\mathrm{CO}^{-}$ operative management sectoral regimes of ecological governance actually succeed in terms of sustainability, thus enhancing the legitimacy of such policies (see Lafferty and Meadowcroft 1996:257 f.). 
However, if we adopt the 'citizen-centred' view of democratic participation outlined in the beginning of this chapter, several of the features of Sweden's existing and 'new environmental governance' could be questioned. It is true that the right of access to information covers all and everyone. It is furthermore true that the remiss procedure is in principle open to all. And it is true that the efforts made to plant LA 21 processes firmly with the grassroots on the local level have been remarkable successful by international comparison. It is, however, equally true that many of these rights and processes are, or have turned out to be, symbolic in character. The channels for citizen participation do not on the whole prove meaningful in terms of actual influence. Instead, the more resourceful actors participating at different stages in the process stand the best chances of actually influencing decisions. As for the future, citizen-centred participation in the NEO processes and climate strategies is best characterised as one where voluntary environmental NGOs are expected to play a mostly complementary role relative to governmental agencies and organised socio-economic sectoral interests.

It may, of course, be argued that this is politically the most realistic way of involving citizen-centred participation in ecological governance. Public participation then functions as a complement to, and a control on, democratically elected representatives at different levels as they make decisions on policies for sustainable development, and as an additional input to ecological problem-solving.

However, problems of legitimacy may arise when ecological governance comes to involve specific channels for compromise and accommodation between governmental bodies and organised sectoral interests. Based on Uhrwing's findings, we may argue that resourceful and thus influential as they are, socio-economic sectoral interests could be assumed to use their position to try to change the balance of the management by objectives strategy for ecological governance to make it more advantageous to them. Indeed, the Cabinet's NEO Bill does not formalise, but only loosely outlines the procedural features of this strategy. The agreements may therefore come to be concluded without the kind of early counsel and public hearings required for permit procedures under the Environmental Code, and may not be fully accessible through citizens' rights to retrieve information, because of the 
possible secrecy of business information. Citizens and environmental NGOs cannot therefore be sure that sectoral agreements actually observe 'the parameters within which co-operative management regimes' are expected to operate under Sweden's NEO strategy (see Lafferty and Meadowcroft 1996:260 f.).

What happens, then, when we confront these mixed patterns and interpretations of Sweden's 'new environmental governance' with our criteria for democratic and participatory ecological governance observing individual autonomy? To begin with individual autonomy, the formal aspects of Sweden's ecological governance seem to have widened the respect for individual integrity and freedom of choice. Ownership of property is no longer the sole condition for legal standing and right to compensation when people experience harm from others' environmental and resource use. When looking at the envisaged 'new environmental governance', one could contend that the pronounced preference for market-based and communicative policy measures changes the context of choice, but leaves much room for individuals to autonomously determine the content of their choices. This might serve to enhance the political legitimacy for the state and its role within ecological governance (see Lundqvist 2001b).

When we turn to democracy and citizen participation, we must conclude that by almost any formal standard, the Swedish process is very open. It provides for widespread citizen and interest group participation, built on general access to rich information, all the way from policy formation to the implementation of specific decisions. In reality, however, the envisaged future structure and process of ecological governance show features that are more elite- than citizen-centred. While both organised sectoral interests and the general public utilise and are bound to the Swedish commons, the former will enjoy a much closer relationship with governmental agencies than the latter. Citizens and environmental NGOs will have a much more complementary role in the structure and processes of ecological governance. Given that the core of Sweden's ecological governance - the NEO strategy - is less formalised, the prospects for citizen and NGO insight and influence will depend heavily on what willpower and resources they can muster. If these groups find themselves fenced off from the commons of NEO processes, the 'new environmental governance' could meet with problems in terms of the legitimacy of 
policies and measures. There is thus every reason to return to this problem of democracy and legitimacy in ecological governance (see below, pp. 197-200). 